\title{
APUD Cell
}

National Cancer Institute

\section{Source}

National Cancer Institute. APUD Cell. NCI Thesaurus. Code C12655.

An endocrine cell that has the capabilities of amine precursor uptake and decarboxylation, and low molecular weight polypeptide hormone secretion. 